Networking Knowledge: Journal of the MeCCSAPostgraduate Network, Vol. 4, No. 1 (2011)

ARTICLE

\title{
The Role of Lucha Libre in the Construction of Mexican Male Identity
}

JAVIER PEREDA, TrinkerMedia, Southampton Solent University

PATRICIA MURRIETA-FLORES, University of Southampton

\begin{abstract}
Lucha Libre has played an important role in Mexican culture since the late 1950s. The sport became famous mainly due to its masked wrestlers, who incorporated their own family traditions, beliefs and fears into the design of their masks, transforming an ordinary person into a fearless character.
\end{abstract}

After the introduction of the Monsters Cinema in the 1930s, Mexican audiences welcomed and adopted characters like Dracula, Nosferatu, Frankenstein and The Werewolf. The success of Monster Cinema in Mexican culture was based on the integration of national legends and beliefs, placing them in local and identifiable concepts in the Mexican popular imagination. Later, Lucha Libre Cinema mixed with Monster Cinema resulting in the birth of new heroes and myths. These emergent paladins of the Mexican metropolis set the cultural and moral standards of that time and how Mexicans wanted to be perceived.

Through an anthropological and historical analysis of Mexican Cinema and Lucha Libre, this paper investigates the main social interaction of male wrestlers who perform as heroes inside the celluloid world and outside of it. We explore how masculinity and the male figure evolves in Lucha Libre Cinema, and the processes that wrestlers have to undergo in order to be able to portray themselves as superheroes of an evolving and fast growing Mexico.

\section{Keywords}

Lucha Libre, Wrestling, Mexican masculinity, horror movies, female empowerment. 
Networking Knowledge: Journal of the MeCCSAPostgraduate Network, Vol. 4, No. 1 (2011)

\section{About Mexican Wrestling}

Lucha Libre is an event in which the worlds of sport and theatre meet, generating a new concept where two or more challengers fight in a blend of Greco-Roman wrestling, acrobatics and other martial arts combined. Lucha Libre was born as an evolved - and very different - form of wrestling whose main essence was largely due to social repercussions, being deeply impregnated with local cultural elements.

It was in 1933 that the first formal wrestling match took place in Mexico along with the foundation of the first company dedicated solely to Wrestling. This match was hosted in what is now known as the Arena Mexico, giving rise to the Lucha Libre concept that rapidly adopted elements from Mexican culture in which one encounters a long tradition in the use of masks and theatrical fights.

As a profoundly popular event, Lucha Libre has an evolving and dynamic character. Therefore to understand it, we need to examine the concepts behind the generation of its iconic wrestlers, the definition of its myths, rituals and rites and to carry out an analysis of its metanarrative.

In current (or modern) cultures, new icons and myths are born daily depending on their sociocultural environment and the necessities of consumers in a globalizing media culture. Umberto Eco (1997: 219) analysed this kind of phenomenon in the United States for the case of Superman, a fully fictional character in which "an unconscious symbolization to identify an object as final sum is not always rational, as projection of tendencies, aspirations and fears, emerged particularly on a single persona in a community as in an entire historic period." At the same time, myths produce rites and rituals, events that can develop as collective or mass events with physical activities that are autonomic, specific and that sometimes have an intention. This results in a game executed already by tradition, superstition, devotion, habits or adaptation into a custom (Dorfles, 1969). The majority of rites are created as a direct result of the myth and Lucha Libre combines these two elements. Whilst mythical narratives usually involve heroic characters who mediate and influence life as we know it, Lucha Libre Media creates and manufactures the 
Networking Knowledge: Journal of the MeCCSAPostgraduate Network, Vol. 4, No. 1 (2011)

storylines of the myths in the Lucha Libre world, generating rituals in which the audience interacts, recreates and adopts a conglomerate of beliefs and stories accepting them as their own.

These so-called myths are usually the result of the marketing trend presented to the audience. This can be understood in the way the wrestling companies develop teasers emulating the launch of a new product or a movie, generating interest in the character within the audience. This is similar to Boxing in which, if a fighter proves to be good and the audience engages with him/her, he/she will get more contracts. In the case of the wrestlers in Lucha Libre, this is based on the response of the audience to the character and the capacity to sell and capitalise on his storyline. The easiest way to promote a wrestler is to list him in championships and matches in which he will bet his mask against another masked wrestler. This generates special events in which the character has the opportunity to become more popular.

The storyline within Lucha Libre is constructed upon a minimum amount of content and very basic information. It is based in the concept of opposites and the simple fight between good and evil in which the good characters are known as Técnicos (Faces), and the evil ones are known as Rudos (Heels) (Fig.1). This builds the metanarrative of every event and every character involved, attempting to be pluralistic in order to reach the masses, enabling wrestlers to present to people their storylines as the truth.

As a postmodern event, Lucha Libre utilises metanarratives to present concepts to the audience. It avoids big stories or epic narratives that might over complicate the story of its characters. Lyotard defines meta-narrative as a story with a narrower scope with totalising claims about reality (Smith, 2006). In this sense, a meta-narrative adopts universal pretensions that simplify the context of the story.

Based on the meta-narrative presented by Lucha Libre, the audience believe that the opponents genuinely hate each other, generating a hyperreal response from it, with real emotions. Hyperreality, as a postmodern element within Lucha Libre is defined by the generation of new models that do not contain real facts. It is a precession of simulacra. Through the adoption of 
Networking Knowledge: Journal of the MeCCSAPostgraduate Network, Vol. 4, No. 1 (2011)

hyperreality, the difference between the imaginary and the real does not exist (Baudrillard, 1994). In this manner, the metanarrative of Lucha Libre can be modified to create entirely new contexts in order to enhance the relationship with the audience and in which hyperreality plays a very important role. Hyperrealistic elements are born from a mixture of capitalism (the creation of characters as products) and the interpretation and acceptance of society based on their social relations and cultural heritage. In the case of Lucha Libre, the adoption of these elements did not happen suddenly. There was a rush of popular culture created by the introduction of Monster Films which began to be produced in the United States in the 1930s. Released in 1931 by Universal Studios, Dracula, the first horror or monster movie to be presented in Mexico was produced by George Melford using mainly Mexican actors in the lead roles. This film quickly begat movies like Frankenstein, The Mummy, The Wolf Man and others, making the Mexican film industry embrace and produce adaptations of horror movies to Mexican culture, transferring to celluloid many of the traditional horror stories of Mexican heritage.

The enormous success of Horror/Monster movies paved the way for Lucha Libre to produce a new genre that took over ten years of development through horror movies. This gave birth to the Cine de Luchadores (Wrestlers Cinema), in which a postmodern amalgamation of elements took place resulting in the creation of the first Wrestlers' movie in 1952: El Enmascarado de PlataThe Silver Masked Man - (Cotter, 2005: 74). Introducing wrestlers to horror and spy movies and blending them with Mexican heritage and traditional stories, the narrative evolved into a local narrative, fragmenting the information provided and making the audience focus on specific places or local identities. This resulted in a faster and stronger link between audience and character (wrestler). The Mexican audience who attended both the Lucha Libre matches and the cinema, were capable of watching their super heroes on the big screen as well as in the wrestling arena in real life. This made the hyperreal elements in Lucha Libre have the same effect created by mass media, where the audience believed that what they were seeing in the matches was real or accurate (Bordieu,1998). As rôle models, these newly born super heroes would have an important rôle in the construction of the modern Mexican male identity, influencing greatly the perception of masculinity in Mexican popular spheres. 
Networking Knowledge: Journal of the MeCCSAPostgraduate Network, Vol. 4, No. 1 (2011)

\section{Defining the heroes: generating male identities through Mexican Cinema}

The Golden Era of Mexican Cinema started with the movie Allá en el Rancho Grande (1937), along with others such as Los Tres Garcia (1946) and Salón México (1948), where the Mexican male stereotype started to become more noticeable. Most of the movies presented a rural Mexico full of ranchers, mariachis, guns, selfless women and tequila. These elements combined, building up the modern origin of the Mexican macho identity. The macho is usually exemplified as something negative, especially in Latin American cultures and its definition is usually associated with such behaviour as heavy drinking, toughness, aggressiveness, and risk taking (Saez, 2009). However, there are also positive elements attached to the macho concept. Qualities like courage, honour, virility and physical strength form part of it representative of protector, provider, and authority figure as well (Saez, 2009).

In the case of the empowerment of women, it was only presented in a matriarchal manner. Mothers and grandmothers were among the most sacred things for men and in early Mexican cinema, women would only regain their empowerment with age. A good example of this is the movie Los Tres Garcia (1946) in which three fearless brothers are subdued by their grandmother. This character played by Sara García is presented with a Cuban cigar and an authoritative walking stick. In the movie, the grandmother even recognises the need for violence to be able to control the machos. Another example would be in the film Lupe Balazos (Gunshots) (Urueta, 1964). The lead character Lupe "Balazos" played by Lucha Moreno, is a heiress of a ranch. She has to be able to portray male attributes in order to be partially accepted into a dominant male society, playing at the same time the role of a male where she is capable of overpowering men in their own macho game, and at times, act feminine enough to be courted by the male characters.

The majority of movies in Mexican cinema of that time constructed the familiar and gender metanarrative giving the female elder the knowledge and strength to control the males in her family. However, in general the macho is always presented overpowering women. If there is a dispute between two men regarding a woman, the only way to solve it is either by fighting or 
Networking Knowledge: Journal of the MeCCSAPostgraduate Network, Vol. 4, No. 1 (2011)

drinking, sending the female to a second plane. The role of the Mexican leading male in traditional cinema is neither very charming nor romantic, and it is usually stated that the female character can physically belong to him without any reciprocity, whereas it is quite normal to flirt with other women.

The way female characters were presented, exalted the illusion of womens' need of protection by a male. In some cases women were depicted as the ones in charge, strong and ready to fight, but still in need of a man to fulfil their romantic desires. Examples of this are La Devoradora (1946) and Doña Bárbara (1943), both played by Maria Félix, which constituted the precedent of women in power in Mexican cinema. Despite iconic figures like María Félix who represent the stereotype of an empowered Mexican woman, in Mexican culture the male has been always dominant over the female persona, and cinema was not very different from reality. Women were normally pictured as overpowered by males depicted as ranchers (Charros), who usually represented successful working class businessmen who were engaged in a constant struggle to overcome the classist Mexican society of 1940s and 1950s. Characters of everyday Mexico were depicted in those films, where real dynamics between rural Mexico and flourishing cities like Guadalajara and Mexico City were portrayed. It wasn't until the end of the 1950 that Mexico started to change its representative imagery, trying to show modernity and the boom of the American Lifestyle as a sign of prosperity. This change in society and class, depicted in celluloid, was directly related to the creation and evolution of superhero wrestlers in Mexican wrestling cinema. In fact, the wrestling superhero identities and the characteristics of the new male character were built around a few men: Rene Cardona, Alfonso Corona and Federico Curiel among others.

This can be traced back to the film El Enmascarado de Plata (1952), in which for the first time wrestlers were presented. Santo el Enmascarado de Plata, was a famous wrestler that gained enormous popularity in the Lucha Libre world and who later transcended into the film industry due to his incursions into popular culture. The character was so renowned that José G. Cruz launched the same year the comic book Santo, el Enmascarado de Plata. Despite the fact that the 1952 movie was not related to Santo, it was at that time that wrestlers began to be portrayed with 
Networking Knowledge: Journal of the MeCCSAPostgraduate Network, Vol. 4, No. 1 (2011)

super-hero characteristics. This movie presented El Médico Asesino (Dr. Assassin) played by the actual wrestler El Médico. This was the first case in which a screen representation of a Lucha Libre character was played by the wrestler himself, adding the hyperreal elements of the storyline to the metanarrative of his persona and embedding this information within real life. This would become important in the construction of the male identity through wrestling cinema and how Mexican fans perceived it. In the case of the movie Huracán Ramirez (1953), the main character was created for the film and was played by a non-wrestler. The actor Daniel Ramírez was charged with playing Huracán Ramírez. Years later Huracán Ramírez became a real wrestling character personified by Daniel García. It was common for these concepts to be later transferred back to the wrestling arena. This is a reflection on how the audience started to embed those hyper real characteristics within the personae of the wrestlers.

In the movie Huracán Ramirez (1952), the plot is a sport drama in which the hero fights against corruption within the wrestling business and his persona is related more to the moral quality of the leading character rather than his toughness or physical strength. In the movie, Huracán Ramírez is an average man who loves his family. Due to the anguish that the dangers of the sport produce in them, he disguises his identity behind a mask in order to hide from his family the fact that he is still a professional wrestler. In the ring he becomes Huracán Ramírez, but outside he is just another regular man who owns a very humble restaurant and even pretends to be disabled to hide his alternative identity. The director and co-writer Joselito Rodríguez portrays the male figure of Huracán Ramírez as a family man who loves his family and would do anything for them or his wife. Family values in Mexican culture are extremely important and this is clearly depicted in the movie; since what Huracán Ramírez fights for is a better future for his family. This made spectators identify themselves with this figure, where in spite of portraying a strong male character, his rôle is not necessarily in opposition to femininity (at least not at all times like in traditional Mexican cinema). However, there are also other characters and elements depicting more macho, traditional male figures within the film. The father of Huracán Ramírez played by Tonina Jackson is presented as a devious character that manages to get what he wants by tricking people. Represented as a simple male, his "only" needs are wrestling and eating and just like any other Mexican macho he is ready to flirt whenever he has the opportunity. 
In this movie, the main male figure started off being portrayed as a well-behaved person, respectful and with high morals. However, despite the depiction of a less dominant character more respectful towards women, the macho essence was still present. In the same film, while working in his restaurant, Huracán gets into a fight where his wife is also involved and chases out the villains. Afterwards, the hero turns to his wife and tells her softly not to get involved in mens" issues, otherwise "...you can grow a moustache". These types of lines were, and still are, common within Mexican culture where, in an apparent attempt to protect women, they would dictate how females must look like and act, thus demonstrating an overpowering male control. However, as previously stated, this would become the beginning of a basic evolution. Progressively, from 1942 to the early 1960s, a metanarrative in which the hero was portrayed as a moral person, always gallant, respectful with women and against any macho current presented in the other Mexican movies, was produced. Morality and family values became key elements in the wrestling ideology. With Lucha Libre as one of the most important events of working class culture, these ideas permeated profoundly the perception of the male identity in Mexican society.

During the early 60s and in subsequent decades, the figure of an incorruptible male hero would be personified by the forementioned El Santo. In his origins, he was presented in the movies only as a crime fighter with very short appearances but long enough to let the audience know his qualities: just, strong, moral and very well educated. This image was supported by his wrestling super hero outfit: a silver mask, boots and cape. His moral correctness played an essential part in the construction of the character. The elements shown in the movies were translated to the ring and accepted as reality (regardless of his real morals as a person). During this time, El Santo was depicted as a character that did not drink alcohol (an action heavily related to male behaviour), asking only for water or fruit juice even in bars or nightclubs. During these decades cabarets and vedettes were at their peak and the early wrestling scene was linked directly to cabaret life due to its connection with the working and middle classes. The vedettes, also known as rumberas, were principal actresses of popular variety shows and they portray the objectification of the female body. Playing an essential rôle within Cabaret nightlife, their performance captivated Mexican audiences and the Americas in general. Vedettes and the nightlife in which women were 
Networking Knowledge: Journal of the MeCCSAPostgraduate Network, Vol. 4, No. 1 (2011)

involved became a very important topic in cinema and theatre, as depicted in the play Cada Quien su Vida (1955) written and directed by Luis G. Basurto and taken later on to the big screen by Julio Bracho (1960). This play presented the cabaret's nightlife and the womens' perspective of it, where the movie scenery was based on the Hollywood star system that presented beautiful women.

Seduction and sexual debauchery was completely forbidden for Santo and surrounded by beautiful - cabaret style - women he relied on being a gentleman with good manners and very respectful towards women. At this point, women started also to be empowered but generally in the rôle of evil characters whose main power was seduction. In the movie Atacan las Brujas (1964), a beautiful witch attempts to seduce Santo, flirting with him in an aggressive way and having apparently, some effect on him. His moral correctness plays an essential role in the scene in which he struggles and ends up saying: "I have to stay alert and get out of here, I am becoming the victim of an infernal seduction". During this time, sexual morality was seen as one of the most essential elements of male heroes in popular culture, this scene being a good example of this.

It was after the construction of the metanarrative of wrestling cinema (mid 1960s) that characters started to evolve towards different cultural perspectives. By this time there was already a substantive list of spy movies and novels, from Mata Hari (1932) and Hitchcock's Secret Agent (1936) to the more modern James Bond movies, Dr. No (1962) and From Russia With Love (1963). In the economic prosperity of the mid 1960s, along with the marketed American way of life and Hollywood's star system, Mexican culture blended with this and attempted to be portrayed as a metropolis, pandering to the values and perceptions of this scenario. This would also be reflected later on in wrestling cinema. In later movies such as Santo y Blue Demon vs. Los Mounstros (1969) and Santo vs. La Mafia del Vicio (1970), the hero was portrayed in a "James Bond" style where he will appear, for instance, taking his girlfriend outside of the city to seduce her, or with two women from the United States sharing kisses and hugs. By this time, Santo's morality would be more relaxed and although he will still not appear drinking alcohol due to his sporting image, when offered a drink he would reply: "No thank you, 
Networking Knowledge: Journal of the MeCCSAPostgraduate Network, Vol. 4, No. 1 (2011)

I almost don't drink". The metanarrative evolved, even his costume was no longer needed and, apart from his mask, Santo is presented wearing modern outfits and suits assimilating him into the spy narrative. The same perspective was applied to other wrestlers such as Los Campeones Justicieros, in which Blue Demon, Mil Mascaras, Black Shadow and Tinieblas among others were presented as spies still sharing the same concept, but presenting a more modern male figure.

\section{Female empowerment and the role of other genders}

The generation of empowered female characters began in the 1940s when men were mainly fighting in World War II, and as a result, women needed to fulfil their rôle as workers. Heroines like The Tiger Woman and The Jungle Girl were born then and by the 1950s the graphic novel Sheena, Queen of the Jungle was taken to television (Cotter, 2005: 135). The increasing role of successful Mexican women in arts, science and other fields but also in working environments, started to be reflected in society. In addition, television series like The Avengers (1961) and Honey West (1965) presented how equality was becoming more and more popular. These changes pushed an alternative current in the Mexican ideology and the wrestler cinema with the incursion of female wrestlers as heroines. With women now being depicted as the ones empowered and with the fighting skills of Lucha Libre, they were perceived at the same level or even higher than men. This resulted in a series of movies by three wrestling women in Las Luchadoras contra el Medico Asesino (1963), Las Luchadoras contra la Momia (1964) and Las Luchadoras contra el Robot Asesino (1968). The popularity of the first two series allowed other female wrestlers to appear in the big screen with movies like Las Lobas del Ring (1965), Las Mujeres Panteras (1967), La Horripilante Bestia Humana (1968) and La Mujer Murcielago (1967). The acceptance of women in the ring and as crime or monster fighters was very welcomed, and became well established in Mexican cinema.

Since then, Mexican society learned through wrestling, or at least assimilated, different visions in relation to what it is to be a leading figure, conveying that was not a matter of gender but about intelligence, stamina and strength which within Lucha Libre are qualities shared by both men and women. In the case of the luchadoras (female wrestlers) the metanarrative is the same and they 
Networking Knowledge: Journal of the MeCCSAPostgraduate Network, Vol. 4, No. 1 (2011)

play roles as heroines or villains. Despite the fact that female wrestlers have been accepted and assimilated into the Lucha Libre world and Mexican culture, it is still evident that there is a majority of male wrestler movies. However, this is probably due to the popularity of the wrestlers more than the actual idiosyncrasy towards the female perspective. In fact, most of the Lucha Libre cinema is represented by two wrestlers: Santo and Blue Demon. They are the main icons of Mexican Lucha Libre, and it can be said that producers took advantage of their real life, sporting popularity to create very popular films within Lucha Libre cinema. In the case of female wrestling cinema this was quite different. While in most of the Lucha Libre cinema the wrestlers played themselves, the female wrestling cinema portrayed actresses as wrestlers. However, the use of actors as wrestlers was not unique to female wrestlers. Characters like Huracán Ramírez, Tinieblas and Neutrón are clear examples of this situation, so it is not surprising that that same formula was utilized for female characters. Indeed, Lucha Libre is a male dominated sport but still welcomes and encourages the empowerment of women. This advocacy is not surprising, as Lucha Libre constitutes the evolution of a circus act in which basic theatrical elements are utilized for the amusement of the audience. Therefore, gender becomes merely a classification for the matches. In fact, the influence of Lucha Libre in leading open-minded ideas regarding sexuality in popular thinking can be testified to by the introduction of gay characters since its early stages.

Gay characters constitute nowadays an elemental part of the Lucha Libre media. Homosexuality and effiminacy in some wrestlers behaviours has been part of Lucha Libre and its history since the 1950s. In its origins, these characters were generated as part of marketing strategies. However, nowadays they have evolved into a manifestation of a culture less oppressive to the gay community, presenting characters known as Exóticos (Exotics). Wrestlers like Cassandro, Polvo de Estrellas, May Flower and Pimpinela Escarlata are now an important part of the wrestling world and they became a positive statement for the gay community (Fig.2). Despite that their characters have helped in the construction of tolerance in diverse social spheres. Homosexuality is still regarded in a negative way but strangely used in wrestling as a power. During the matches, "gayness" is used as a weapon, in which wrestlers who act as homophobic men are afraid to be too close to the exotic wrestlers who attempt to use their sexuality against 
Networking Knowledge: Journal of the MeCCSAPostgraduate Network, Vol. 4, No. 1 (2011)

them, and since there are no rules against kissing, inappropriate touching or just pretending to be in love with somebody, the exotic wrestlers play a very important role in the narrative of Lucha Libre.

Exotic wrestlers have even been transcended to the social activism movement called Lucha Social, in which non-wrestling characters use the metanarrative of wrestlers to project strength and give pride to the community. An example of this is Super Gay, a gay activist who fights against homophobia and he can be seen on gay parades or any other gay demonstrations in Mexico. Lucha Libre has now been attached to social activism due to the strong and rightful attributes embedded within the characters of the wrestlers. Through decades of mediated information through cinema, graphic novels, television and Lucha Libre matches, the wrestling heroes have established a level of acceptance and recognition by modern Mexican society. The metanarrative generated through time by Lucha Libre, has allowed social activists to use this information to their advantage. The utilization of the wrestler as a hero in real social campaigns generates an automatic response within society. One of the most notorious cases is Super Barrio, a character created by the necessity to defend people's rights. The earthquake of 1985 destroyed a great part of Mexico City, leaving people on the streets. The "Asamblea de Barrios" (Neighborhood Assembly) was created due to the struggle for the right to housing. Super Barrio became the mediated spokesperson for this movement. Knowing the media power that wrestling had within popular culture, he presented himself with his uniform in red and golden colours and the letters SB on his chest. By 1987 he proclaimed himself as the defender of the tenants of the poor neighbourhoods.

Super Barrio has worked not only in México but also in other Latin American countries. Brazil, Venezuela, Chile and Argentina are some places in which the example of Super Barrio has opened doors for social activism generating also Neighbourhood Assemblies. The image created of the Mexican superhero portrayed as a wrestler already embeds with power and righteousness the persona, regardless of the character who plays it. In this sense, in an evolution from a more or less typical male dominant character, Lucha Libre has changed through time, playing an important role in the construction of Mexican male identity, helping in the edification of a more 
Networking Knowledge: Journal of the MeCCSAPostgraduate Network, Vol. 4, No. 1 (2011)

equalitarian society in terms of gender. In this sense, in modern Lucha Libre regardless of how dominant is the male figure, it is more the wrestler him/herself that generates the empowered figure (Fig.3).

\section{Conclusion}

As the evolution of Catch-as-Catch-Can and Wrestling, Lucha Libre has transformed the social perspective of an entire country like Mexico and influenced many others. It has been able to absorb socio-cultural icons from Mexican culture in order to create the metanarrative of the behaviour of individual wrestling characters. However, a constant was that male and female figures were normally constrained to follow specific rules or behaviour according to their gender. Lucha Libre allowed these structural paradigms in popular spheres to be broken, developing new concepts in which the empowerment of the persona is built through their actions and moral compass instead of the traditional abuse of the stronger sex.

The creation of the Wrestler-Superhero is the result of an asexual empowerment in which each person can retrieve the narrative elements of a specific character and adapt them to a specific mean. These elements can be also perceived by people outside of the Lucha Libre world. In this way, social activism has been able to use Lucha Libre to convey messages and represent ideas and ideals according to different needs. The metanarrative of Lucha Libre plays by its own rules and it does not obey traditional costumes. This has helped in the evolution of the perception of gender and identity. Nowadays the development of the characters and the narrative within Lucha Libre is directly related to the political and social movements of the country. It represents the markers for morality within a specific time in society. This case, unique to Mexico, took place as a result of the existence of particular elements: a show that attracted the majority of the social spheres of society, the evolution of technology, the introduction of Monster Cinema to Mexican culture and its adaptation to local legends and the identification of the average Mexican male with the stories that generated the heroes of Lucha Libre. 
Networking Knowledge: Journal of the MeCCSAPostgraduate Network, Vol. 4, No. 1 (2011)

\section{Bibliography}

ARANA, F. \& PANIAGUA, M. 2007. Mascaras y Luchadores, San Sebastian, España, Centro Charro Matías de Nostálgicos Descarridos.

BARTHES, R. 2000. Mythologies, London, Vintage.

BASURTO, L. G. 1974. Cada quien su vida, México, Novarro.

BISCHOFF, E. \& ROBERTS, J. 2006. Controversy Creates Cash, New York, World Wrestling Entertainment Books.

BORDIEU, P. 1998. On Television, New York, The New Press.

COTTER, B. 2005. The Mexican masked wrestler and monster filmography, Jefferson, N.C., McFarland \& Co.

DORFLES, G. 1969. Nuevos ritos, nuevos mitos, Barcelona, Lumen.

ECO, U. 1997. Apocalipticos e Integrados, Barcelona, Lumen.

ELIADE, M. 1991. Images and symbols, Princeton, N.J., Princeton University Press.

FERNANDEZ, A. 2004. Santo, el Enmascarado de Plata: mito y realidad de un heroe moderno, México City, Colegio de Michoacan - Conaculta.

FERNANDEZ, J. 2011. LuchaWiki [Online]. Lucha Wiki. Available: http://luchawiki.com/index.php? title=Main_Page [Accessed 4 March 2011].

FRIENDLY, M. 2001. Visualizing categorical data Cary, N.C., Sas Institute.

GROBET, L. 2006. Espectacular de lucha libre, México City, Trilce.

INEGI. 2010. Volumen y porcentaje de la poblacion segun profese alguna religion y tipo de religion. [Online]. México City: INEGI. Available: http://www.inegi.org.mx/ [Accessed 2nd of January 2011].

RASCON, M. 2007. Veinte años de Superbarrio [Online]. México City: La Jornada. Available: http://www.jornada.unam.mx/2007/06/19/index.php?section=opinion\&article=018a2pol [Accessed 8/1/2011 2011]. 
Networking Knowledge: Journal of the MeCCSAPostgraduate Network, Vol. 4, No. 1 (2011)

SOLORZANO, J. \& CAMACHO, J. 2002. El Santos contra la Tetona Mendoza, México City, La Jornada.

SWATOS, W. 1998. Encyclopedia of religion and society, Walnut Creek, California, AltaMira Press.

\section{Films}

CARDONA, R. (1963). Las Luchadoras contra El Médico Asesino. Mexico, Zima Entertainment

CARDONA, R. (1965). Las Lobas del Ring. Mexico, RTC

CARDONA, R. (1967). Las Mujeres Panteras. Mexico, RTC

CARDONA, R. (1968). La Horripilante Bestia Humana. Mexico, RTC

CARDONA, R. (1969). Santo contra Capulina. Mexico, Laguna Films

CARDONA, R. (1971). Santo contra los cazadores de cabezas. Mexico, Laguna Films

CREVENNA, A. (1968). Pasaporte a la muerte. Mexico, Televisa

CURIEL, F. (1963). Neutrón contra el Dr. Caronte. Mexico, Televisa

CURIEL, F. (1971). Los Campeones Justicieros. Mexico, RTC

CURIEL, F. (1971). Santo contra la Mafia del Vicio. Mexico, RTC

CURIEL, F. (1972). Vuelven los Campeones Justicieros. Mexico, RTC

DELGADO, M. (1973). Santo y Blue Demon vs Drácula y el Hombre Lobo Mexico, Zima Entertainment

DELGADO, M. (1974). Santo y Blue Demon contra el doctor Frankenstein. Mexico, RTC

DÍAZ, J. (1968). Atacan las Brujas. Mexico, Zima Entertainment

FERNÁNDEZ, E. (1948). Salón México. Mexico, Televisa

FUENTES, F. D. (1943). Doña Barbara. Mexico,

FUENTES, F. D. (1946). La Devoradora. Mexico

HERNANDEZ, H. \& RIVERA, H. (2006). Los Pajarracos. Mexico, RTC 
Networking Knowledge: Journal of the MeCCSAPostgraduate Network, Vol. 4, No. 1 (2011)

MARTÍNEZ, G. (1969). Blue Demon contra Las Invasoras. Mexico, Zima Entertainment

MARTÍNEZ, G. (1970). Santo y Blue Demon contra Los Monunstros. Mexico, RTC

PÉREZ, R. (1969). Santo en la frontera del terror. Mexico, Zima Entertainment

PÉREZ, R. (1981). Santo contra el asesino de la TV. Mexico, Zima Entertainment

RODRÍGUEZ, I. (1947). Los Tres García. Mexico, WB

RODRÍGUEZ, J. (1962). El misterio de Huracán Ramírez. Mexico, RTC

RODRÍGUEZ, J. (1967). La venganza de Huracán Ramirez. Mexico, RTC

SALVADOR, J. (1969). Mil Máscaras. Mexico, RTC

SOLER, J. (1959). La Última Lucha. Mexico, RTC

SOLER, J. (1970). Santo contra Blue Demon en la Atlántida. Mexico, RTC

URUETA, C. (1964). Lupe Balazos. Mexico, Cinematográfica Filmex S.A.

URUETA, C. (1968). Blue Demon contra cerebros infernales. Mexico, Zima Entertainment

URUETA, C. (1968). Blue Demon contra las diabólicas Mexico, Zima Entertainment

Figures 
Networking Knowledge: Journal of the MeCCSAPostgraduate Network, Vol. 4, No. 1 (2011)

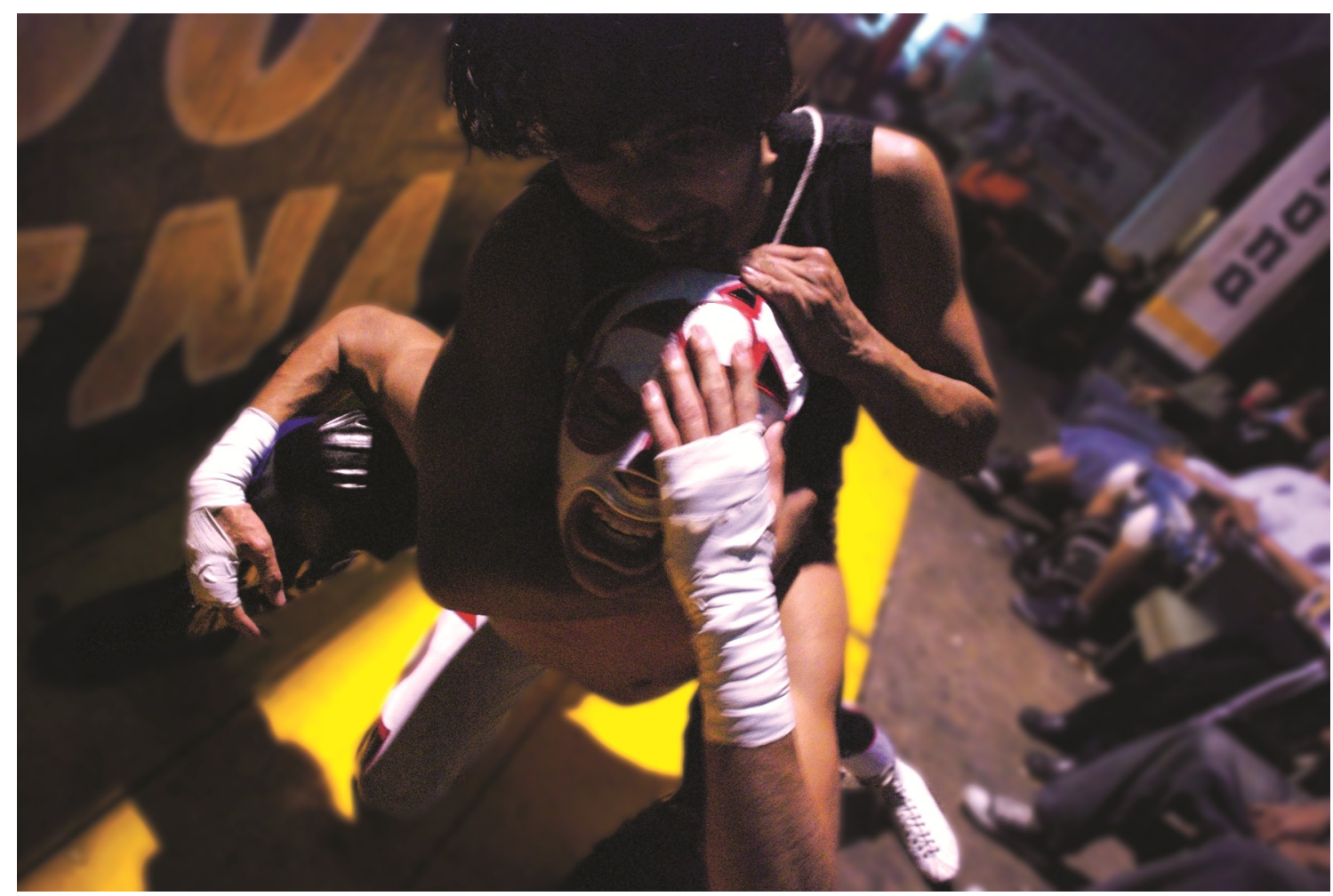

Fig.1 Fight between a Rudo (Black) and a Técnico (White). Photo: Javier Pereda 
Networking Knowledge: Journal of the MeCCSAPostgraduate Network, Vol. 4, No. 1 (2011)

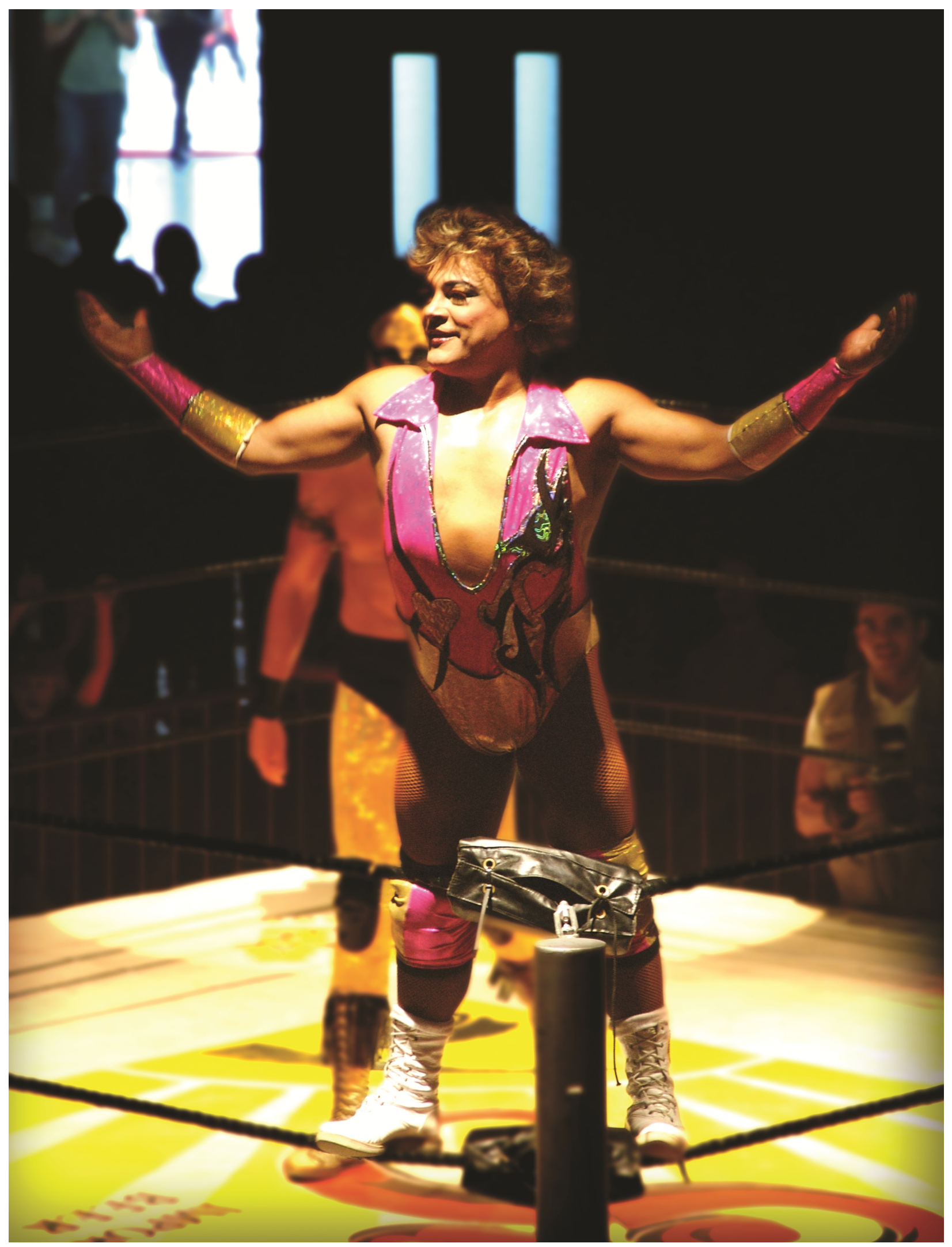


Networking Knowledge: Journal of the MeCCSAPostgraduate Network, Vol. 4, No. 1 (2011)

Fig. 2 Cassandro and his colourful outfit. Photo: Javier Pereda

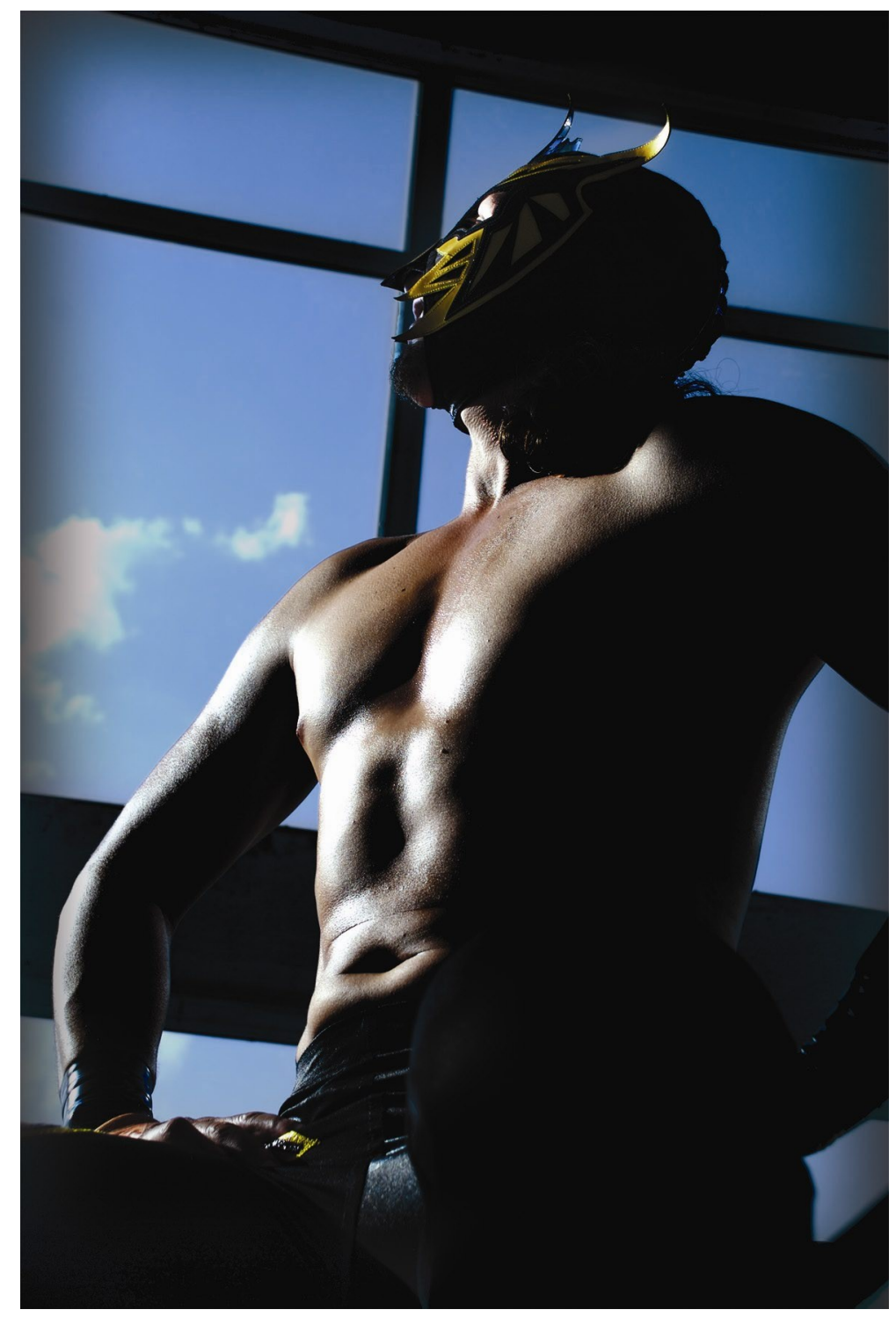

Fig. 3 Cybelius poses for the camera after a training session. Photo Javier Pereda 